\title{
Satisfaction, quality and loyalty of public services
}

\author{
(iD) Nilza Borda Luna ${ }^{1}$ \\ ${ }^{1}$ Universidad César Vallejo
}

Satisfacción, calidad y fidelización de los servicios públicos

\begin{abstract}
The objective of the research was to determine the incidence of satisfaction and quality in the loyalty of external users. The loyalty of users or customers are fundamental elements for the growth and development of organizations and that is influenced by various factors. After a focus group and through Pareto analysis, it was determined that the indicated variables are those with the greatest implication. For the research, a quantitative approach of non-experimental design was used, of explanatory scope with a random sample made up of 384 users of the public entity and whose results showed that the variables satisfaction and quality affect $72.9 \%$ on loyalty, through of the Cox and Snell model.
\end{abstract}

Keywords: satisfaction, quality, loyalty, brand and service.

\section{Resumen}

La investigación presentó como objetivo determinar la incidencia de la satisfacción y la calidad en la fidelización de los usuarios externos. La fidelización de los usuarios o clientes son elementos fundamentales para el crecimiento y desarrollo de las organizaciones y que es influido por diversos factores. Luego de un focus group y a través del análisis de Pareto se determinó que las variables indicadas son las de mayor implicancia. Para la investigación se utilizó un enfoque cuantitativo de diseño no experimental, de alcance explicativo con una muestra aleatoria conformada por 384 usuarios de la entidad púbica y cuyos resultados arrojaron que las variables satisfacción y calidad inciden en $72,9 \%$ sobre la fidelización, a través del modelo Cox y Snell.

Keywords: satisfacción, calidad, fidelización, marca y servicio.

\section{Introduction}

User loyalty is the result of a set of factors that will have a significant impact on it. Many public and private institutions fail due to deficiencies in the service they provide. Thus, theorists such as Pérez (2006), Mesén (2011) Peña, Ramírez and Osorio (2014) defined loyalty as a set of strategic processes with the aim of having a long and consolidated relationship with users and customers, whose purpose is oriented to give it an organizational solidity. Two important aspects of loyalty are brand and service. Reyes (2011) affirms that the recognized brand is the consolidation of the organization, recognized by users, external and internal, in compliance with the offer or quality standards.

User satisfaction from the perspective of Kotler, (2009), Calva (2009) understand that it is an evaluative process of the various aspects of the services provided by the organization, exceeding or 
equaling the expectations generated around the expected service. Therefore, every organization must establish a set of procedures (Borges 2009), assuming a standardization process; the personalized treatment, according to Martínez (2009) that would guarantee the respect and the right of the user and in this way meet the user's expectations.

Medina, Medina and Vigueras (2011) Velandia (2007) and Farías (2010) with reference to quality affirm that the perception of the subjects about the service provided by the organization, generating satisfaction as well as dissatisfaction. To measure quality, the SERVice PERFormance model, created by Cronin and Taylor (1994), where the service provided by the organization is measured through customer perception. The level of perception of the user will allow to define the level of loyalty or loyalty. The Servperf model presents five categories or dimensions to evaluate: responsibility, reliability, security, empathy and tangible elements. (Cronin and Taylor 1994).

In the research process, it was of a basic type and of a non-experimental and transactional design, Hernández, Fernández and Baptista (2014) and Ñaupas, Mejía, Novoa and Villagómez (2013), being the random sample made up of 384 users of the public service.

The descriptive results obtained after applying the instruments to external users of the public institution, Table 1 indicates, satisfaction of $10.4 \%$ perceives a high level, $28.1 \%$ perceive a low level and $61.5 \%$ perceives a medium level. Regarding quality, $49.0 \%$ perceive a high level, $51.0 \%$ perceive a low level. In relation to loyalty, $51.6 \%$ perceive a high level, $48.4 \%$ perceive a low level.

Table 1

Levels of perception of satisfaction, quality and loyalty

\begin{tabular}{lrrrrrr}
\hline & \multicolumn{2}{c}{ Satisfaction } & \multicolumn{2}{c}{ Quality } & \multicolumn{2}{c}{ Loyalty } \\
Levels & \multicolumn{1}{c}{ Frequency } & \multicolumn{1}{c}{ Percentage } & Frequency & Percentage & Frequency & Percentage \\
\hline High & 40 & 10.4 & 188 & 49.0 & 198 & 51.6 \\
Low & 108 & 28.1 & 196 & 51.0 & 186 & 48.4 \\
Half & 236 & 61.5 & 0 & 0.0 & 0 & 0.0 \\
Total & 384 & 100.0 & 384 & 100.0 & 384 & 100.0 \\
\hline
\end{tabular}

Logistic regression was used to test the general hypothesis, whose statistical results indicate that the report has been adequate, with statistical significance and a level of influence of $72.9 \%$ according to the Cox and Snell model, which explain the effect. on the dependent variable.

Table 2

General hypothesis testing

\begin{tabular}{lcc}
\hline & & Cox and Snell's R \\
seneral and specific hypotheses & $\begin{array}{c}\text { Nagelkerke's R } \\
\text { square } \\
\text { Logarithm of } \\
\text { likelihood }\end{array}$ & \\
\hline
\end{tabular}

Satisfaction and perceived quality influence the loyalty of users of a public institution.

$.000 \mathrm{a}$ , 729

1,000

a. The estimation has ended at iteration number 20 because the maximum number of iterations has been reached. The final solution cannot be found 
For the contrast of specific hypothesis 1, logistic regression was used, whose statistical results indicate that the report has been adequate, with a statistical significance and with a level of influence of $66.7 \%$ according to the Cox and Snell model that explain the effect on the dependent variable.

Table 3

Specific hypothesis test 1

\begin{tabular}{lccc}
\hline General and specific hypotheses & $\begin{array}{c}\text { Logarithm of } \\
\text { likelihood }\end{array}$ & $\begin{array}{c}\text { Cox and Snell's R } \\
\text { squared }\end{array}$ & $\begin{array}{c}\text { Nagelkerke's R } \\
\text { square }\end{array}$ \\
\hline $\begin{array}{l}\text { Satisfaction and perceived quality influence the } \\
\text { brand dimension of the loyalty of users of a public } \\
\text { institution. }\end{array}$ & $.000 \mathrm{a}$ &, 667 &, 939 \\
\hline
\end{tabular}

a. The estimation has ended at iteration number 20 because the maximum number of iterations has been reached. The final solution cannot be found

For the contrast of specific hypothesis 2, logistic regression was used, whose statistical results indicate that the report has been adequate, with a statistical significance and with a level of influence of $70.8 \%$ according to the Cox and Snell model that explain the effect on the dependent variable.

Table 4

Specific hypothesis test 2

\begin{tabular}{lccc} 
General and specific hypotheses & $\begin{array}{c}\text { Logarithm of } \\
\text { likelihood }\end{array}$ & $\begin{array}{c}\text { Cox and Snell's R } \\
\text { squared }\end{array}$ & $\begin{array}{c}\text { Nagelkerke's R } \\
\text { square }\end{array}$ \\
\hline $\begin{array}{l}\text { Satisfaction and perceived quality influence the } \\
\text { service dimension of the loyalty of users of a public } \\
\text { institution }\end{array}$ & $.000 \mathrm{a}$ &, 708 &, 944 \\
\hline
\end{tabular}

a. The estimation has ended at iteration number 20 because the maximum number of iterations has been reached. The final solution cannot be found.

\section{Discussion}

The statistical results allow us to establish that although the perception of the variables independently has a moderate level of appreciation in the satisfaction variable, in the other variables, quality and loyalty is low, being logical when we relate the variables subjectively. However, this is corroborated when the statistical analysis is carried out with the logistic regression tests, evidencing the influence of the independent variables in a significant way.

These findings confirm the results of previous research such as that of Cabana, Cortés, Vega and Cortés (2016) when they affirm that the loyalty of users -students- requires effective management processes (satisfaction and quality, among others) that guarantee institutional life, requiring organizational reengineering processes for this.
Likewise, the results obtained by García, Cepeda and Ruíz (2012) allow us to confirm the influence of satisfaction with the quality perceived by customers, with an R2 index of 0.892 . The results obtained by Vergara and Quesada (2011) also allow us to confirm the influence of the study variables, where the authors used the instrument proposed by Oh (1999) and Servqual and their results showed the influence of the variables on the quality of service borrowed.

The various theorists referred to, as well as the findings regarding user loyalty, only confirm that this fact is due to the influence of various factors, which for the present case is satisfaction and quality as direct vectors $(66.7 \%)$ and that $33.3 \%$ is due to other factors not contemplated in the present investigation. 


\section{Conclusions}

Satisfaction and perceived quality influence user loyalty in a public institution, according to the Nagelkerke index at $72.9 \%$. Likewise, in the first specific hypothesis, satisfaction and perceived quality influence the brand in $66.7 \%$ and the second specific hypothesis, satisfaction and perceived quality influence loyalty services in $70.8 \%$

\section{References}

[1] Cabana, Segundo, Cortés, Felicindo, Vega, Domingo and Cortés, Rodrigo. (2016) Analysis of the Loyalty of Engineering Students with their Higher Education Center: Challenges of Educational Management, in "University Training" Vol. 9 No. 6 - 2016. Universidad de La Serena, Fac. Of Engineering, Dept. of Engineering Industrial, Casilla 554, La Serena - Chile. URL: https://scielo.conicyt.cl/pdf/formuniv/v9n6/ar t09.pdf

[2] Calva, Juan (2009). User satisfaction: research on information needs. Mexico: Autonomous University of Mexico Editorial Fund.

[3] Cronin, Joseph and Taylor, Steven (1994). Servperf vs. Servqual: reconciling performancebased and perceptions minus expectations measurement of service quality. Journal of Marketing 58 (1): 125-131.

[4] García, Jerónimo, Cepeda, Gabriel and Ruíz, David (2012) Customer satisfaction and its relationship with the perception of quality in the Fitness Center: use of the CALIDFIT scale in the "Journal of Sports Psychology" 2012. Vol. 21, no. 2, pp. 309-319

[5] Hernandez, Roberto. Fernández, Carlos and Baptista, Pilar (2014). Research methodology Mexico: Mc. Graw-Hill / Interamericana SA Sixth edition,

[6] Kotler, Philip (2009). Marketing Directorate. Recovered from:http://www.promonegocios.net/mercad otecnia/satisfaccion-cliente.htm
[7] Medina, Manuel. Medina, Elvira and Vigueras, Rosa (2011). Analysis of the perceived quality in users of community social services. Spain: Abendua

[8] Mesén, V. (2011). Customer loyalty: accounting concept and perspective. Costa Rica: University of Costa Rica Publishing Fund.

[9] Ñaupas, Humberto, Mejía, Elías, Novoa Eliana and Villagómez Alberto (2013) methodology of scientific research and thesis preparation. Pacarina del Sur [Online], year 5, no. 20, July-September, 2014. ISSN: 20072309.

[10] Pérez, D. (2006). Customer loyalty. CRM technique. The new applications of modern marketing. Spain: EOI.

[11] Reyes, DL (2011). The marks, seal of guarantee and security. Panama: Eriex

[12] Stefanía Peña Escobar Gloria S. Ramírez Reyes Juan C. Osorio Gómez (2014) Evaluation of a customer loyalty strategy with system dynamics. "Engineering Magazine Universidad de Medellín" vol. 14, No. 26 pp. 87-104 ISSN 16923324 - January-June 2015/208 p. Medellin Colombia

[13] Velandia, Freddy. (2007). Satisfaction and quality: analysis of the equivalence or not of the terms. Peru. Marcio

[14] Vergara, Juan and Quesada, Víctor (2011) Analysis of the quality in the service and satisfaction of the students of Economic Sciences of the University of Cartagena through a model of structural equations. "Electronic journal of educational research" On-line version ISSN 1607-4041. REDIE vol.13 no.1 Ensenada Jan. 2011. URL. http://www.scielo.org.mx/scielo.php?script=s ci_arttext\&pid=S1607-40412011000100007

\section{Correspondence}

Nilza Borda Luna

nilzabordaluna@gmail.com 